\title{
Dampak Pemanasan Pulau Perkotaan (Urban Heat Island) pada Peningkatan Tren Curah Hujan Ekstrem dan Aerosol di Megapolitan Jakarta Sejak 1986
}

\section{Impacts of Urban Heat Island to the Increasing Trend of Rainfall Extreme and Aerosol in Megapolitan Jakarta Since 1986}

\author{
FADLI SYAMSUDIN ${ }^{(1)}$ DAN SOPIA LESTARI ${ }^{(1)(2)}$ \\ ${ }^{(1)}$ Pusat Teknologi Pengembangan Sumberdaya Wilayah, Badan Pengkajian dan Penerapan Teknologi, \\ Gedung Geostech 820, Kawasan Puspiptek, Serpong, Tangerang Selatan 15314 \\ ${ }^{(2)}$ Graduate School of Earth SciencesThe University of Melbourne \\ sopia.lestari@bppt.go.id
}

\begin{abstract}
Impacts of Urban Heat island (UHI) to the rainfall extreme and aerosol have been studied using daily rainfall data and monthly aerosol concentration of $\mathrm{NO}_{2}, \mathrm{SO}_{2}$, and SPM in the megapolitan Jakarta and mountainous regions of Bogor and Citeko taken from the Agency of Meteorology Climatology and Geophysics (BMKG) during 1986-2012. Harmonic analysis is applied to remove the seasonal monsoon from rainfall and aerosol time series data in order to have clear trend results, and then the trend signifancies are performed by Mann-Kendall statistical method. The results show that the impacts of UHI are very clear with the increasing trends of rainfall extremes as indicated by total numbers of 40, 50, 100 $\mathrm{mm} /$ year, and of aerosol concentrations in the megapolitan Jakarta and surroundings and correspond with its rates of 0.17 day/year, 0.17 day/year, and 0.04 day/year, and 3.7e-004 ppm/year $\left(\mathrm{NO}_{2}\right)$ and 0.148 $\mathrm{ppm} /$ year $\left(\mathrm{SO}_{2}\right)$, respectively. Adversely, the decreasing trends have been occurring significantly to both rainfall extremes and aerosol concentrations in the mountainous regions of Bogor and Citeko. This study implies that UHI causes increasing trend of aerosol concentrations in the megapolitan Jakarta and to be the main triggers of increasing trend of rainfall extremes that have been made in severe trail of floods since 1986.
\end{abstract}

Keyword: Urban heat island, rainfall extreme, aerosol, trend

\begin{abstract}
ABSTRAK
Dampak pemanasan pulau perkotaan (urban heat island (UHI)) pada curah hujan ekstrem dan aerosol telah dikaji dalam penelitian ini menggunakan data curah hujan harian dan konsentrasi aerosol bulanan $\left(\mathrm{NO}_{2}, \mathrm{SO}_{2}\right.$, dan SPM) di stasiun Badan Meteorologi Klimatologi dan Geofisika (BMKG) pada megapolitan Jakarta dan wilayah pegunungan Bogor dan Citeko dari 1986-2012. Analisis harmonik dilakukan untuk menghilangkan pengaruh musiman pada hasil tren data curah hujan dan selanjutnya signifikansi tren tersebut diuji dengan metoda statistik Mann-Kendall. Hasil penelitian menunjukkan dampak pemanasan pulau perkotaan $(\mathrm{UHI})$ telah terjadi secara nyata dengan tren peningkatan curah hujan ekstrem dari indikator total hari hujan 40,50 dan $100 \mathrm{~mm} /$ tahun dan konsentrasi aerosol di wilayah megapolitan Jakarta dan sekitarnya dengan laju tren masing-masing sebesar 0.17 hari/tahun, 0.17 hari/tahun, dan 0.04 hari/tahun, dan 3.7e-004 ppm/tahun $\left(\mathrm{NO}_{2}\right)$ dan $0.148 \mathrm{ppm} / \operatorname{tahun}\left(\mathrm{SO}_{2}\right)$. Namun sebaliknya terjadi tren penurunan di wilayah pegunungan Bogor dan Citeko. Hasil penelitian ini menunjukkan ada indikasi peningkatan UHI menyebabkan kenaikan konsentrasi aerosol di megapolitan Jakarta dan kondisi ini menjadi trigger peningkatan curah hujan ekstrem yang berdampak pada intensitas banjir yang semakin meningkat sejak tahun 1986.
\end{abstract}

Kata kunci: Pemanasan pulau perkotaan, curah hujan ekstrem, aerosol, tren

\section{PENDAHULUAN}

Dewasa ini terjadi peningkatan kepadatan penduduk dan perubahan penggunaan lahan yang membuat luasan hutan dan daerah terbuka hijau di perkotaan semakin berkurang. Hal tersebut telah memberikan dampak yang sangat nyata pada kualitas dan keberlanjutan lingkungan. Populasi dan aktivitas manusia yang meningkat di kota besar Asia memerlukan lahan untuk pembangunan rumah, pertambangan, dan industri. Hal ini yang telah menyebabkan masalah lingkungan, seperti: polusi udara, efek pulau panas di perkotaan (urban heat island $(\mathrm{UHI})$ ), bahkan beberapa perubahan pada iklim lokal dan regional ${ }^{(1)}$. 
Megapolitan Jakarta adalah salah satu kota terbesar di Asia Tenggara yang telah mengalami degradasi kualitas lingkungan akibat meningkatnya aktivitas manusia yang melakukan perubahan penggunaan lahan dari hutan menjadi industri dan perumahan, selain peningkatan penggunaan moda transportasi yang makin menambah kepekatan $\mathrm{CO}_{2}$ di udara. Kondisi ini telah menyebabkan peningkatan suhu yang sangat signifikan selama 30 tahun sejak 1986 dengan suhu rerata harian meningkat sebesar $0,8^{\circ} \mathrm{C}^{(2)}$.

Pemanasan pulau perkotaan (Urban Heat Island (UHI)) terjadi sebagai akibat adanya perubahan suhu, albedo, evapotranspirasi, dan fluks energi. UHI telah menjadi topik penting dewasa ini, karena efeknya terhadap intensitas curah hujan lokal $^{(3)}$. Sebagai dampak dari perubahan suhu tersebut, terjadi pengaruh yang sangat signifikan peningkatan suhu di wilayah perkotaan terhadap awal waktu kemunculan hujan dan intensitas curah hujan lokal yang dapat menyebabkan banjir ${ }^{(4)}$.

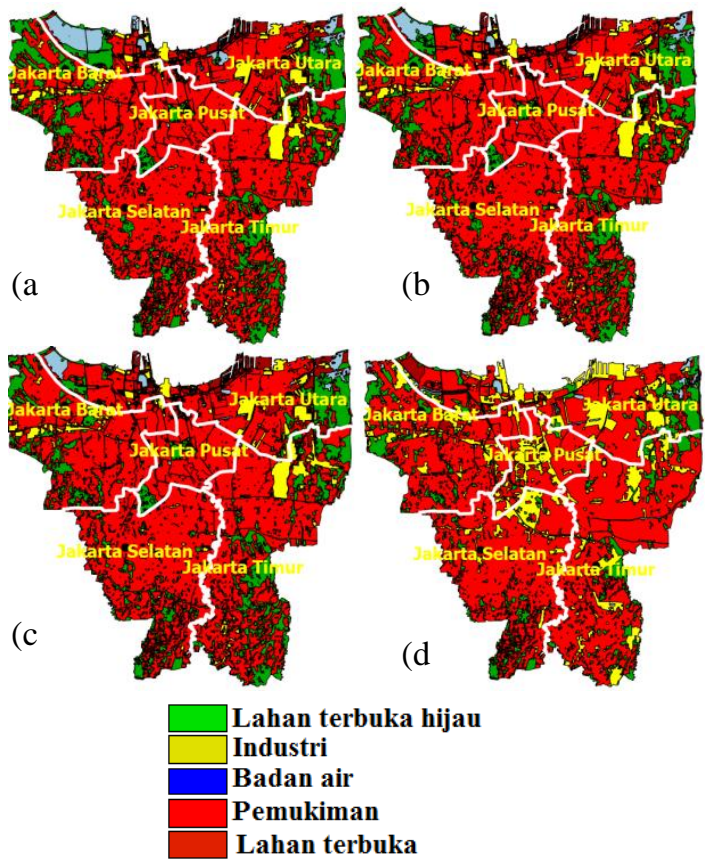

Gambar 1. Peta perubahan tutupan lahan: lahan terbuka hijau, industri, badan air, pemukiman, lahan terbuka (dalam Ha) di Jakarta pada tahun a) 1997, b) 2004 , c) 2009, d) $2012^{8)}$.

Banyak penelitian UHI menggunakan data tutupan lahan dan suhu ${ }^{(5,6)}$ dengan mengkaji perubahan lahan terbuka hijau, industri, pemukiman dan badan air di Jakarta pada tahun 1989 dan $2002^{(7)}$, namun belum ada studi yang meneliti efek dan hubungannya dengan curah hujan dan aerosol seiring perubahan penggunaan lahan yang terjadi pada tahun 1997,
2004, 2009 dan 2012. Dalam penelitian ini, data meteorologi permukaan dan aerosol dari Badan Meteorologi Geofisika dan Klimatologi (BMKG) digunakan untuk melihat pengaruh dampak UHI terhadap curah hujan ekstrem dan aerosol di wilayah megapolitan Jakarta. Data curah hujan ekstrem dan aerosol di wilayah pegunungan, yaitu stasiun BMKG di Bogor dan Citeko digunakan sebagai pembanding untuk melihat laju perubahan yang terjadi. Hipotesis penelitian ini adalah UHI akan memberikan laju peningkatan curah hujan dan konsentrasi aerosol yang sangat signifikan dibandingkan wilayah pegunungan, dimana aktivitas manusia yang berdampak pada perubahan penggunaan lahan, transportasi dan kawasan industri masih sedikit.

\section{BAHAN DAN METODE}

Penelitian ini menggunakan data primer curah hujan harian dan konsentrasi aerosol bulanan. Data curah hujan dan aerosol di stasiun yang terletak di wilayah megapolitan Jakarta dan pegunungan digunakan untuk melihat perbedaan kontras perubahan lingkungan akibat polusi, berdasarkan parameter aerosol, yaitu: $\mathrm{SO}_{2}, \mathrm{NO}_{2}$, dan SPM (Suspended Particulate Matter).

Tabel 1. Data Curah Hujan Harian

\begin{tabular}{ccccc}
\hline No & Nama Stasiun & Lintang & Bujur & Curah hujan \\
\hline 1 & Jakarta & -6.17 & 106.82 & $1986-2008$ \\
2 & Halim & -6.27 & 106.88 & $1986-2008$ \\
3 & Tanjung Priok & -6.10 & 106.87 & $1986-2008$ \\
4 & Cengkareng & -6.12 & 106.65 & $1986-2008$ \\
5 & Bogor & -6.50 & 106.75 & $1986-2008$ \\
6 & Citeko & -6.70 & 106.93 & $1986-2008$ \\
7 & Curug & -6.23 & 106.65 & $1986-2008$ \\
8 & Pondok & -6.26 & 106.75 & $1986-2008$ \\
9 & Betung & -6.11 & 106.13 & $1986-2008$ \\
\hline
\end{tabular}

Kualitas data curah hujan dan aerosol diperiksa dengan uji keseragaman. Ketika data lolos uji keseragaman, data dapat dianalisis. Data curah hujan yang digunakan mulai dari tahun 1986 sd. 2008, sedangkan curah hujan selama 2009-2012 tidak digunakan karena banyaknya data kosong dan tidak lolos uji keseragaman. Analisis harmonik digunakan untuk menghilangkan pengaruh musiman dari data deret waktu (time series) agar tren (trend) yang terjadi bukan lagi karena efek lokal dan musiman. Selanjutnya, metoda statistik MannKendall digunakan untuk menguji tren setiap $\operatorname{data}^{(9)}$. 
Tabel 2. Data Aerosol Bulanan

\begin{tabular}{|c|c|c|c|c|}
\hline No & $\begin{array}{l}\text { Nama } \\
\text { Stasiun }\end{array}$ & SPM & $\mathrm{SO}_{2}$ & $\mathrm{NO}_{2}$ \\
\hline 1 & Ancol & $\begin{array}{c}1986- \\
1989,1991- \\
1992,1994- \\
2012\end{array}$ & $\begin{array}{l}2006- \\
2013\end{array}$ & $\begin{array}{l}2006- \\
2013\end{array}$ \\
\hline 2 & Bandengan & $\begin{array}{c}1986- \\
1989,1991- \\
1996,1998- \\
2012 \\
1986-\end{array}$ & $\begin{array}{l}2006- \\
2013\end{array}$ & $\begin{array}{l}2006- \\
2013\end{array}$ \\
\hline 3 & Glodok & $\begin{array}{c}1987,1991- \\
1997,1999- \\
2012\end{array}$ & $\begin{array}{l}2006- \\
2013\end{array}$ & $\begin{array}{l}2006- \\
2013\end{array}$ \\
\hline 4 & Kemayoran & $1986-2012$ & $\begin{array}{l}1986- \\
2013\end{array}$ & $\begin{array}{l}1985- \\
2013\end{array}$ \\
\hline 5 & Monas & 2004-2012 & $\begin{array}{l}2006- \\
2013\end{array}$ & $\begin{array}{l}2006- \\
2013\end{array}$ \\
\hline 6 & Cileduk & $\begin{array}{c}1986- \\
1988,1991- \\
2002,2005- \\
2012\end{array}$ & - & - \\
\hline 7 & Citeko & $1998-2012$ & - & - \\
\hline 8 & Darmaga & $2006-2012$ & - & - \\
\hline 9 & Tangerang & $1993-2012$ & - & - \\
\hline
\end{tabular}

Uji keseragaman dilakukan dengan 4 tes statistik (homogeneity tests), yaitu Standard normal homogeneity, Buishand range, Pettit, dan Von Neumann ${ }^{(10)}$.

Persamaan harmonik dibawah ini digunakan untuk menghilangkan komponen musiman dari deret waktu curah hujan dan aerosol (1) ${ }^{(11)}$.

$$
\begin{gathered}
Y(t)=y_{0}+\sum_{n=1}^{n=\infty} Y_{n} \sqrt{2} \sin (n 2 \pi f t \\
\left.-\varphi_{n}\right) \ldots .(1)
\end{gathered}
$$

Dimana $Y_{0}=$ Amplitudo, $Y_{n}=$ Akar dari nilai komponen harmonik $\mathrm{n}, \mathrm{f}=$ frekuensi dasar $(50 \mathrm{~Hz})$ dan $\varphi_{n}=$ fase komponen harmonik $n$.

Berikut persamaan Mann Kendall (2):

$$
S
$$$$
=\sum_{k=1}^{n-1} \sum_{j=k+1}^{n} \operatorname{sgn}\left(x_{j-} x_{k}\right)
$$

Dimana $X_{j}$ dan $X_{k}$ adalah nilai tahunan dari tahun $\mathrm{j}$ dan $\mathrm{k}$, j>k, dan

$$
\operatorname{sgn}\left(x_{j}-x_{k}\right)=\left\{\begin{array}{r}
1 \text { if } x_{j}-x_{k}>0 \\
0 \text { if } x_{j}-x_{k}=0 \\
-1 \text { if } x_{j}-x_{k}<0 \ldots .
\end{array}\right.
$$

Nilai $\operatorname{Var}(\mathrm{S})$ dapat dihitung untuk $\mathrm{n}<10$ :

$$
\operatorname{VAR}(S)=\frac{1}{18}[n(n-1)(2 n+5)]
$$

Persamaan di atas digunakan jika jumlah data $(n<10)$, namun jika $n>10$ maka terdapat nilai yang sama sehingga $S$ dihitung dengan persamaan berikut:

$$
\begin{aligned}
& V A R(S)=\frac{1}{18}\left[n(n-1)(2 n+5)-\sum_{p=1}^{q} t_{p}\left(t_{p}-\right.\right. \\
& 1(2 t p+5)
\end{aligned}
$$

Dimana $q$ adalah jumlah grup yang sama dan $t_{0}$ adalah jumlah nilai data di grup p. S dan $\operatorname{Var}(\mathrm{S})$ dihitung dengan menggunakan tes $Z$ :

$$
Z=\left\{\begin{array}{cc}
\frac{S-1}{\sqrt{\operatorname{VAR(S)}}} & \text { if } S>0 \\
0 & \text { if } S=0 \\
\frac{S+1}{\sqrt{\operatorname{VAR(S)}}} & \text { if } S<0
\end{array} \ldots .\right.
$$

Nilai Z untuk menentukan signifikansi deret waktu. Nilai negatif atau positif dari z menandakan bahwa tren deret waktu tersebut turun atau naik.

\section{HASIL DAN PEMBAHASAN}

\subsection{Curah hujan ekstrem di megapolitan Jakarta dan daerah pegunungan Bogor}

Total hari curah hujan lebih dari $40 \mathrm{~mm} /$ tahun, $50 \mathrm{~mm} /$ tahun, dan $100 \mathrm{~mm} /$ tahun dihitung untuk menganalisis curah hujan ekstrem ${ }^{(12)}$.

Laju jumlah hari hujan selama 23 tahun untuk curah hujan lebih dari $40 \mathrm{~mm} / \mathrm{tahun}, 50 \mathrm{~mm} / \mathrm{tahun}$, dan $100 \mathrm{~mm} /$ tahun secara berturut-turut adalah 0.17 hari/tahun, 0.17 hari/tahun, dan 0.04 hari/tahun 


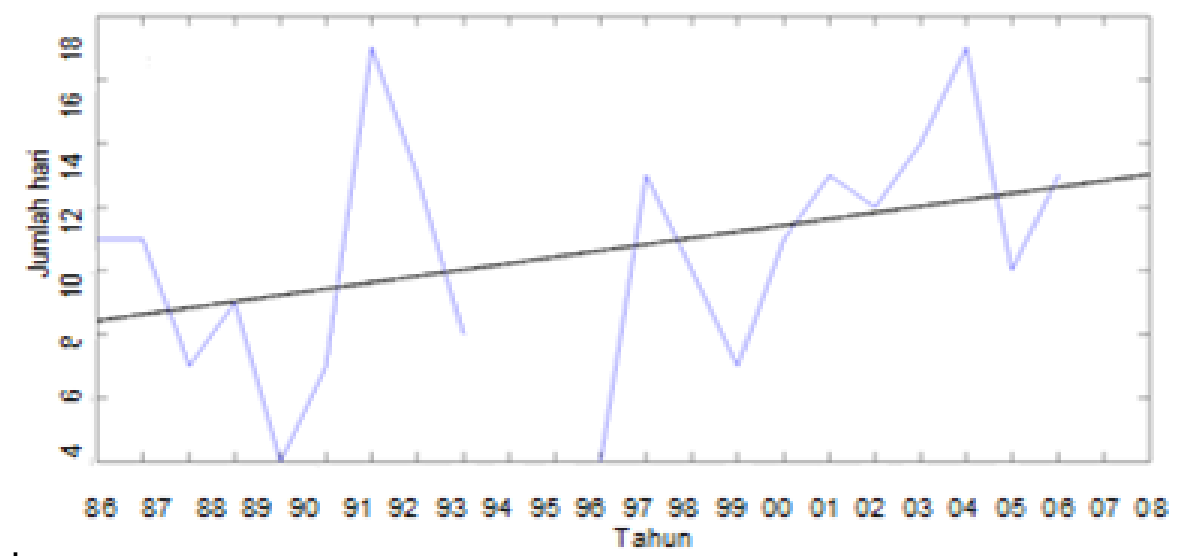

Gambar 2. Jumlah hari curah hujan lebih dari 40 mm/tahun selama 1986-2008 di Stasiun Meteorologi Jakarta. Terjadi peningkatan tren dengan persamaan $y=0,2^{*} x+8,2$ dan tingkat kepercayaan (signifikansi) $90 \%$

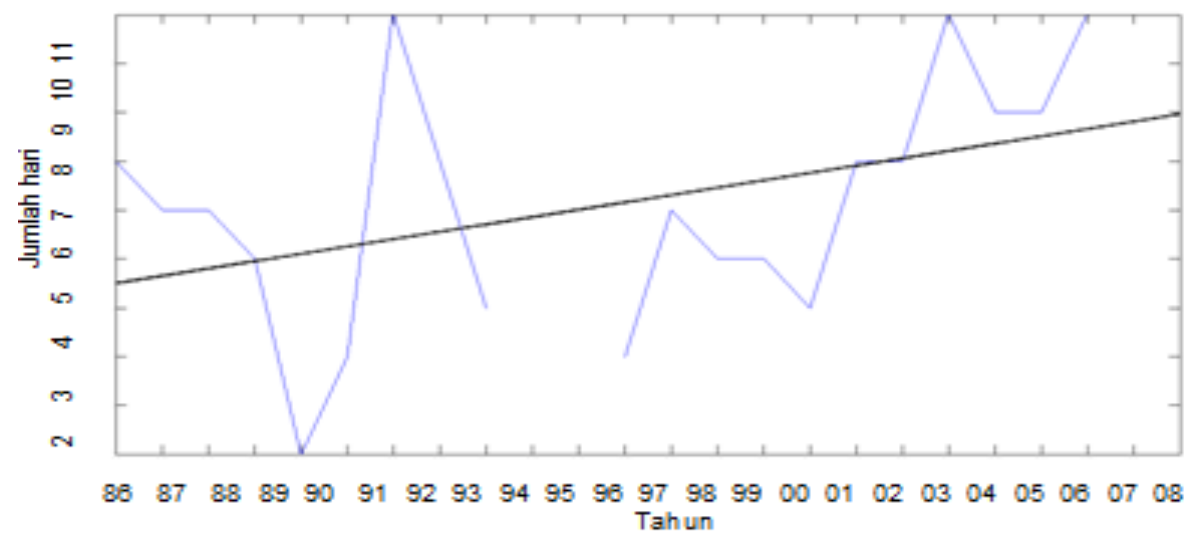

Gambar 3. Jumlah hari curah hujan lebih dari $50 \mathrm{~mm}$ selama 1986-2008 di Stasiun Meteorologi Jakarta. Terjadi peningkatan tren dengan persamaan $y=0,15^{*} x+5,4$ dan tingkat kepercayaan (signifikansi) $90 \%$

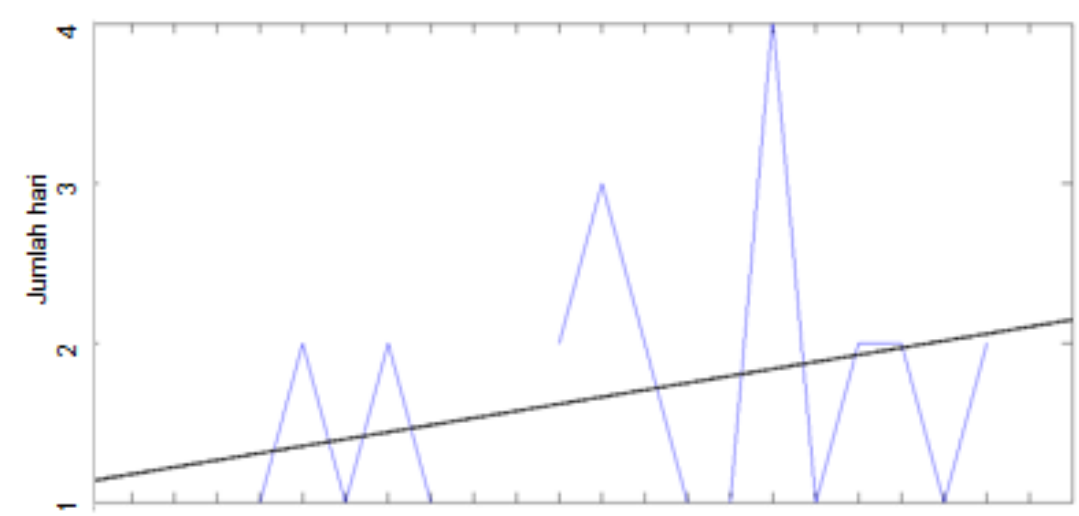

$\begin{array}{llllllllllllllllllllllll}86 & 87 & 88 & 89 & 90 & 91 & 92 & 93 & 94 & 95 & 96 & 97 & 98 & 99 & 00 & 01 & 02 & 03 & 04 & 05 & 06 & 07 & 08\end{array}$

Gambar 4. Jumlah hari curah hujan lebih dari $100 \mathrm{~mm}$ selama 1986-2008 di Stasiun Meteorologi Jakarta. Terjadi peningkatan tren dengan persamaan $y=0,044^{*} x+0,09$ dan tingkat kepercayaan (signifikansi) $90 \%$ 


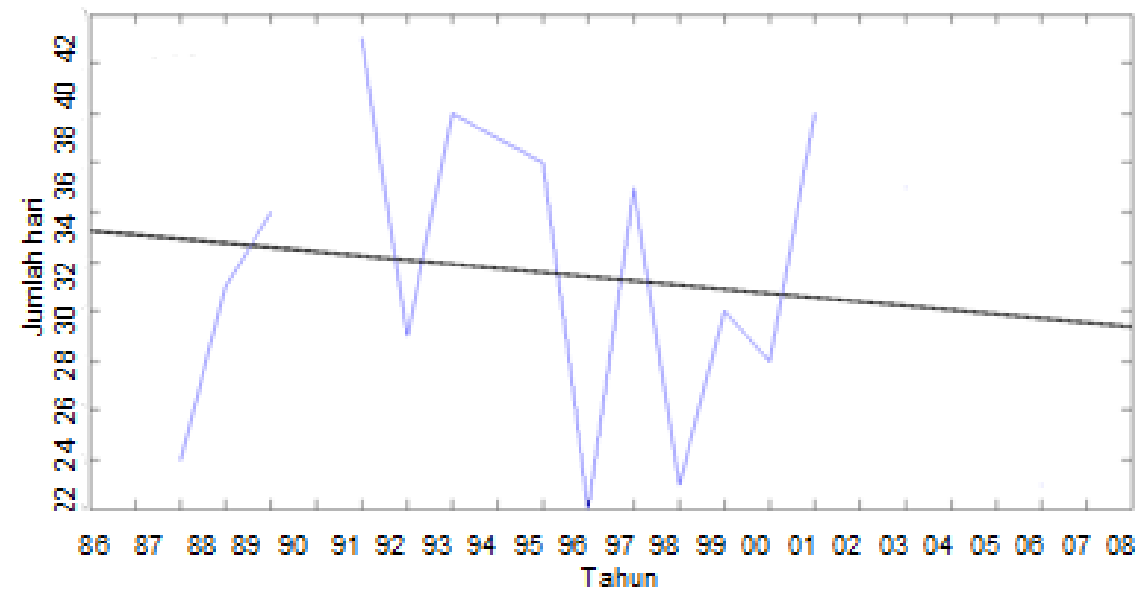

Gambar 5. Jumlah hari curah hujan lebih dari $40 \mathrm{~mm}$ selama 1986-2008 di Stasiun Meteorologi Bogor. Terjadi penurunan tren dengan persamaan $y=-0,17^{*} x+33$ namun tidak signifikan dengan uji Mann-Kendall.

Curah hujan ekstrem di Stasiun Meteorologi Jakarta menunjukkan peningkatan tren secara signifikan sementara di Stasiun Meteorologi Bogor yang terletak di wilayah pegunungan di luar Jakarta menunjukkan penurunan tren secara signifikan. Hasil di atas sesuai dengan penelitian sebelumnya yang menjelaskan bahwa terdapat peningkatan tren jumlah hari hujan lebih dari 50 $\mathrm{mm} /$ hari dan $100 \mathrm{~mm} /$ hari di Jakarta secara signifikan pada tahun $1961-2010^{(13)}$.

\subsection{Konsentrasi aerosol di megapolitan Jakarta dan daerah pegunungan Citeko}

Konsentrasi aerosol, seperti: $\mathrm{SO}_{2}, \mathrm{NO}_{2}$, dan SPM dihasilkan dari pembakaran batubara (industri) dan pembakaran bensin (kendaraan).

Konsentrasi aerosol mengalami tren yang meningkat secara signifikan di Stasiun BMKG di sekitar megapolitan Jakarta (dalam makalah ini diwakili stasiun meteorologi Kemayoran), namun tidak terjadi peningkatan tren konsentrasi aerosol yang signifikan di stasiun BMKG di wilayah pegunungan di luar Jakarta (dalam makalah ini diwakili stasiun meteorologi (iteko).
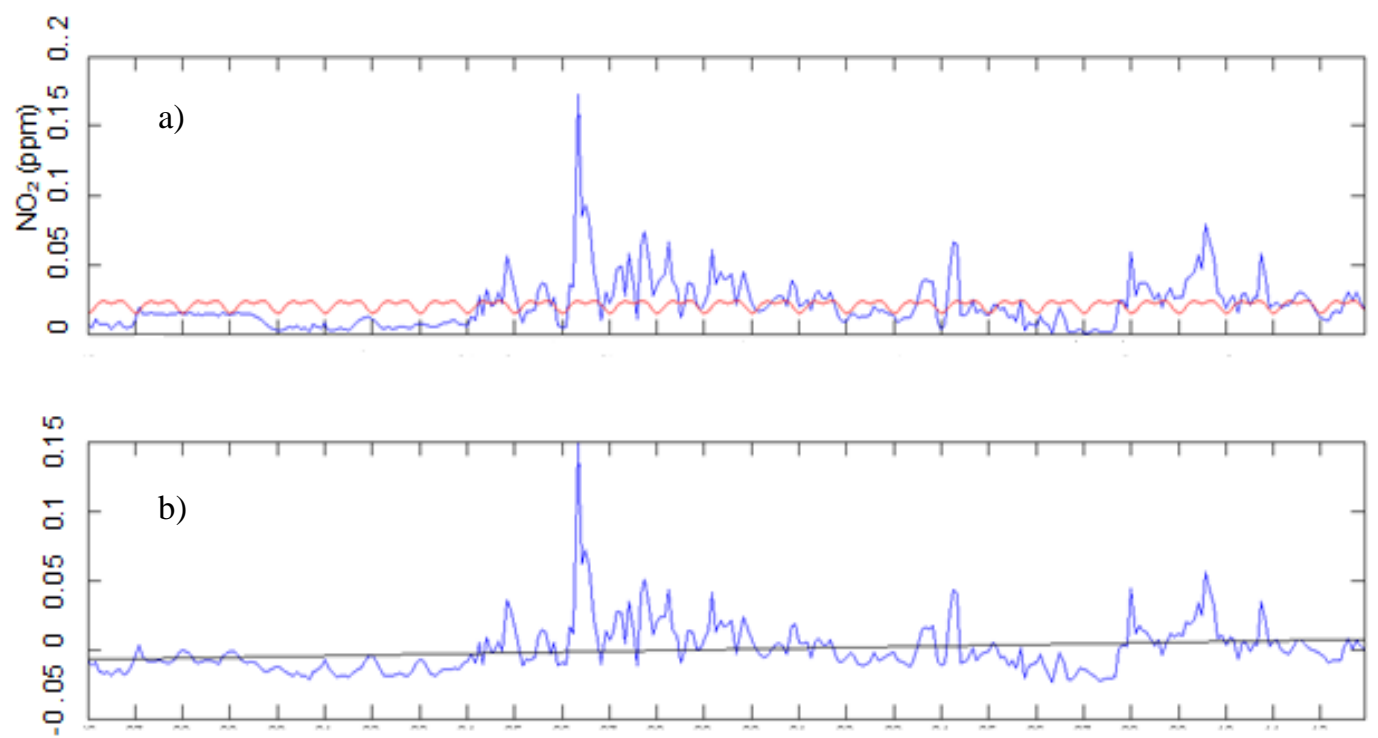

$\begin{array}{llllllllllllllllllllllllll}86 & 87 & 88 & 89 & 90 & 91 & 92 & 93 & 94 & 95 & 96 & 97 & 98 & 99 & 00 & 01 & 02 & 03 & 04 & 05 & 06 & 07 & 08 & 09 & 10 & 11\end{array}$ Tahun

Gambar 6. $\mathrm{NO}_{2}$ di stasiun Kemayoran: a) deret waktu $\mathrm{NO}_{2}$ selama 1986-2012 (25 tahun) biru) dan $\mathrm{NO}_{2}$ musiman (merah), b) tren data $\mathrm{NO}_{2}$ musiman yang telah difilter dengan persamaan: $\mathrm{y}=$ $4,5 e-005^{*} x-0,0074$ dan tingkat kepercayaan (signifikansi) 99\% dengan uji Mann-Kendall. Laju tren 3.7e-004 ppm/tahun. 


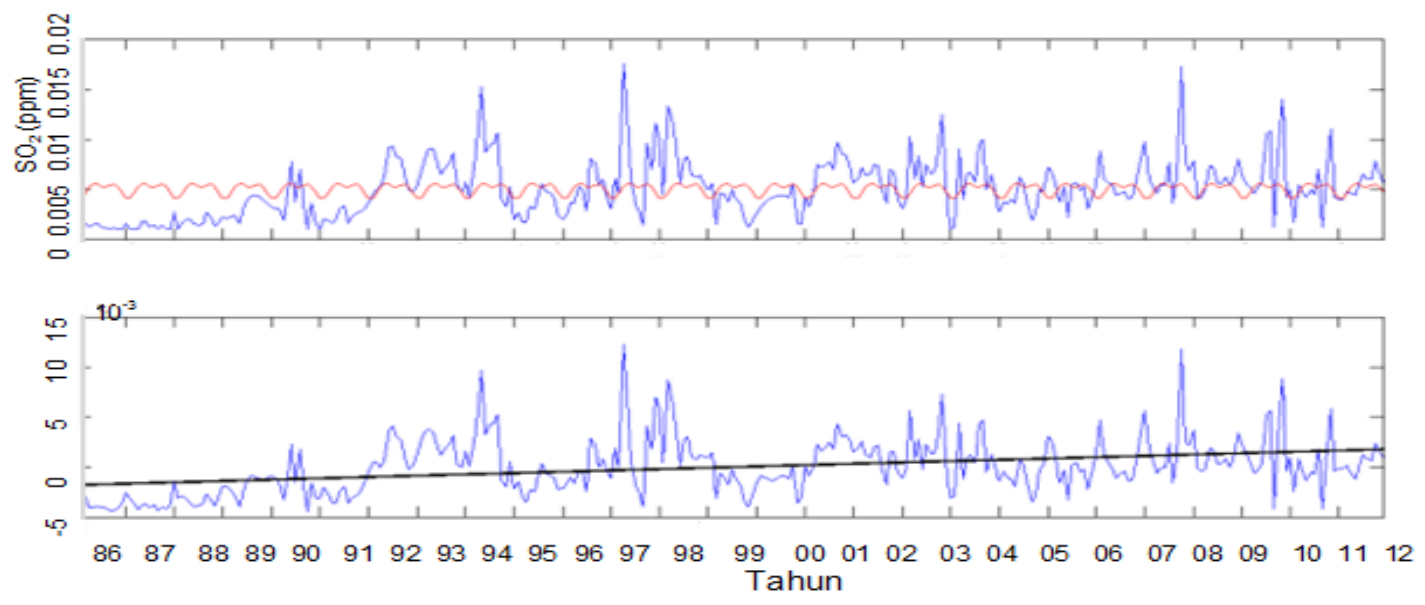

Gambar 7. $\mathrm{SO}_{2}$ di stasiun Kemayoran: a) deret waktu $\mathrm{SO}_{2}$ selama 1986-2012 (25 tahun) biru) dan $\mathrm{SO}_{2}$ musiman (merah), b) tren data $\mathrm{SO}_{2}$ musiman yang telah difilter dengan persamaan: $y=1,1 e-005^{*} x-0,0018$ dan tingkat kepercayaan (signifikansi) $99 \%$ dengan uji Mann-Kendall. Laju tren 0.148 ppm/tahun

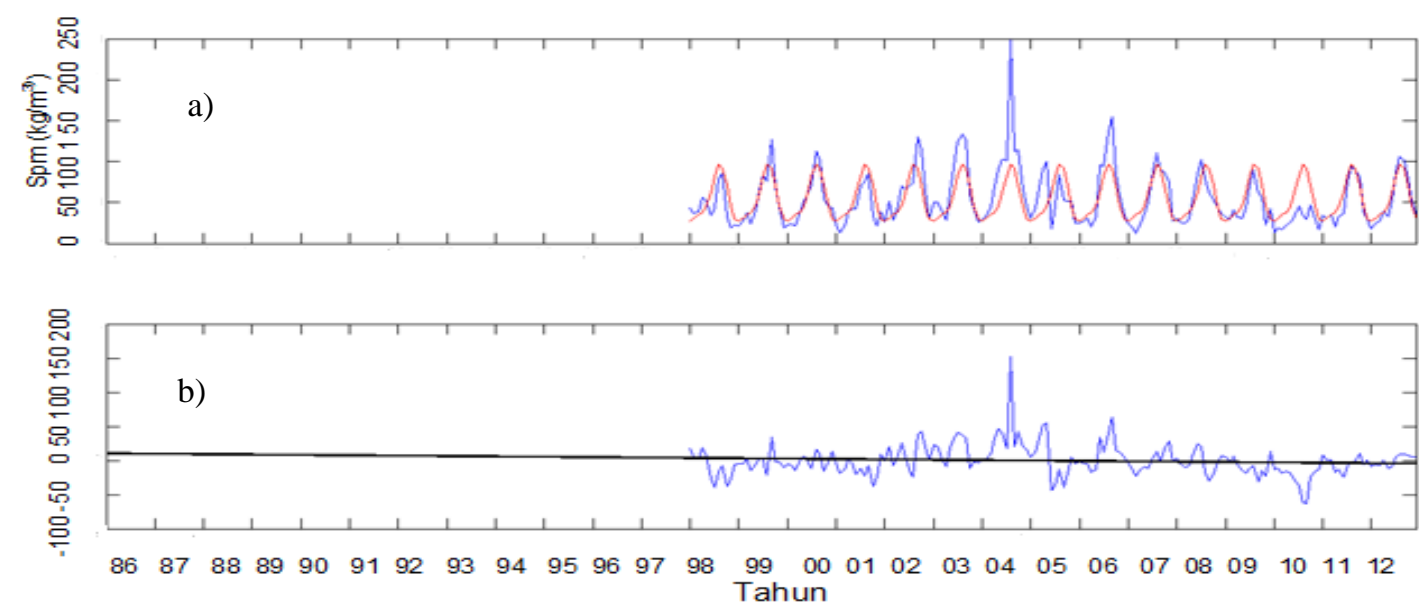

Gambar 8. Konsentrasi SPM di stasiun BMKG Citeko: a) deret waktu SPM selama 1986-2012 (25 tahun) (biru) dan data musiman SPM (merah), b) tidak ada tren yang signifikan dari data SPM musiman

Tabel 3. Persamaan Linear untuk tren curah hujan

\begin{tabular}{|l|l|l|l|l|l|}
\hline No. & $\begin{array}{l}\text { Nama } \\
\text { stasiun }\end{array}$ & $\begin{array}{l}\text { Jumlah } \\
\text { hari hujan } \\
(\mathrm{mm} / \text { thn })\end{array}$ & $\begin{array}{l}\text { Tipe tren } \\
\text { (tingkat } \\
\text { kepercayaan) }\end{array}$ & Persamaan tren & $\begin{array}{l}\text { Laju } \\
\text { (hari/thn) }\end{array}$ \\
\hline 1 & Kemayoran & $\geq 40$ & Naik $(90 \%)$ & $\mathrm{y}=0,2^{*} \mathrm{x}+8,2$ & 0,17 \\
\hline 2 & Kemayoran & $\geq 50$ & Naik $(90 \%)$ & $\mathrm{y}=0,15^{\star} x+5,4$ & 0,17 \\
\hline 3 & Kemayoran & $\geq 100$ & Naik $(90 \%)$ & $\begin{array}{l}\mathrm{y}=0,044^{\star} \mathrm{x}+ \\
0,09\end{array}$ & 0,04 \\
\hline 4 & Bogor & $\geq 40$ & $\begin{array}{l}\text { Turun (tidak } \\
\text { signifikan) }\end{array}$ & $\mathrm{y}=-0,17^{*} \mathrm{x}+33$ & - \\
\hline
\end{tabular}


Tabel 4. Persamaan Linear untuk tren aerosol

\begin{tabular}{|l|l|l|l|l|l|}
\hline No. & $\begin{array}{l}\text { Nama } \\
\text { stasiun }\end{array}$ & $\begin{array}{l}\text { Nama } \\
\text { parameter } \\
\text { aerosol }\end{array}$ & $\begin{array}{l}\text { Tipe tren } \\
\text { (tingkat } \\
\text { kepercayaan) }\end{array}$ & Persamaan tren & $\begin{array}{l}\text { Laju } \\
\text { (ppm/thn) }\end{array}$ \\
\hline 1 & Kemayoran & $\mathrm{NO}_{2}$ & Naik (99\%) & $\begin{array}{l}\mathrm{y}=4,5 \mathrm{e}-005^{*} \mathrm{x}- \\
0,0074\end{array}$ & $3.7 \mathrm{e}-004$ \\
\hline 2 & Kemayoran & $\mathrm{SO}_{2}$ & Naik (99\%) & $\begin{array}{l}\mathrm{y}=1,1 \mathrm{e}-005^{*} \mathrm{x}- \\
0,0018\end{array}$ & 0,148 \\
\hline 3 & Citeko & $\mathrm{SPM}$ & Tidak ada tren & - & - \\
\hline
\end{tabular}

Penelitian sebelumnya di wilayah Amazon menyebutkan bahwa aerosol dapat memicu pembentukan awan konvektif dan peningkatan curah hujan ekstrim ${ }^{(14)}$. Dengan demikian, tren peningkatan konsentasi aerosol di kota Jakarta dapat menjadi pemicu meningkatnya tren curah hujan ekstrem di wilayah ini.

\section{KESIMPULAN}

Dampak pemanasan pulau perkotaan (Urban Heat Island (UHI)) telah terjadi secara nyata dengan tren peningkatan curah hujan ekstrem dari indikator total hari hujan 40, 50 dan 100 $\mathrm{mm} /$ tahun dan konsentrasi aeorosol di wilayah megapolitan Jakarta dan sekitarnya dengan laju tren masing-masing sebesar 0.17 hari/tahun, 0.17 hari/tahun, dan 0.04 hari/tahun serta $3.7 \mathrm{e}-$ $004 \mathrm{ppm} / \mathrm{tahun}\left(\mathrm{NO}_{2}\right)$ dan $0.148 \mathrm{ppm} / \mathrm{tahun}$ $\left(\mathrm{SO}_{2}\right)$. Namun sebaliknya terjadi tren penurunan di wilayah pegunungan Bogor dan Citeko. Hasil penelitian ini menunjukkan ada indikasi peningkatan UHI menyebabkan kenaikan konsetrasi aerosol di megapolitan Jakarta dan kondisi ini menjadi trigger peningkatan curah hujan ekstrem yang berdampak pada intensitas banjir yang semakin meningkat sejak tahun 1986 di Jakarta.

\section{PERSANTUNAN}

Terima kasih disampaikan pada Badan Meteorologi, Klimatologi dan Geofisika, Dinas Perhubungan Jakarta, Badan Pertanahan Nasional (BPN) yang telah menyediakan data untuk digunakan dalam penelitian ini. Ucapan terima kasih juga diucapkan kepada reviewer dan editor yang telah memberikan masukan pada penulisan jurnal ini.

\section{DAFTAR PUSTAKA}

1. Lin, C.-Y.; W.-C. Chen, P.-L. Chang, and Y.F.Sheng, (2011), Impact of Urban Heat Island Effect on Precipitation Over a Complex Geographic Environment in Northern Taiwan, American Meterological Society, 50: 339-353.

2. Brandsma, T., (2012), Hourly Meteorological Observations of Batavia/Jakarta in the 18661980 Period, International Workshop on the Digitization of Historical Climate Data the
New SAC\&D Databases and Climate Analysis in the Asian Region, 2012, Bogor.

3. Dixon, P.G., and T.L . Mote, (2003), Patterns and Causes of Atlanta's Urban Heat IslandInitiated Precipitation, American Meteorological Society, 42: 1273- 1284.

4. Shepherd, J.M., (2005), A review of Current Investigations of Urban-Induced Rainfall and Recommendations for the Future, Earth Interactions, American Meteorological Society, Washington, (pp. 1- 27).

5. Tokairin, T., A. Sofyan,.., \& T. Kitada, (2010), Effect of Land Use Changes on Local Meteorological Conditions in Jakarta: Indonesia: Toward the Evaluation of The Thermal Environment of Megacities in Asia, Int. J. Climatol, 30: 1931-1941.

6. Marpaung, F., (2012), Urban Thermal Analysis of MODIS Images for Examining Heat Island Effects in Jakarta, Master thesis, National Central University.

7. Tursilowati, L., J.T.S. Sumantyo, H. Kuze, and E.S. Adiningsih, (2012). Relationship between urban heat island phenomenon and land use/land cover changes in JakartaIndonesia. Journal of Emerging Trends in Engineering and Applied Sciences, 3: 645653.

8. Lestari, S., (2014), Studi Efek Heat Island di Jakarta dan Hubungannya dengan Curah Hujan Ekstrim dan Peningkatan Aerosol, Master thesis, Universitas Indonesia.

9. Salmi, T., A. Maata , P. Antilla. T., R.. Airola, , T. Amnell, (2002), Detecting Trends of Annual Values of Atmospheric Pollutans by the Mann-Kendall test and Sen's Slope Estimates-The Excel Template Application Makesens, Available from http://www.ilmanlaatu.fi/ ilmansaasteet/julkaisu/pdf/MAKESENSManu al_ 2002.pdf,(viewed November 13, 2015).

10. Wijngaard, J. B., A. M. G. Klein Tank, and G. P. Können, (2003), Homogeneity of 20th century European daily temperature and precipitation series, Int. J. Climatol, 23: 679-692. 
11. Katznelson, Y., (2004), Introduction to Harmonic Analysis, Cambridge University Press, Cambridge.

12. Endo, N., J. Matsumoto, and T. Lwin, (2009), Trends in precipitation extremes over southeast Asia, SOLA, 5: 168-171.

13. Siswanto, G.J. van Oldenborgh, $G$, van der Schrier, R. Jilderda, and B. van den Hurk
(2016), Temperature, extreme precipitation, and diurnal rainfall changes in the urbanized Jakarta city during the past 130 year, Int. J. Climatol, 36: 3207-3225.

14. Andreae, M.O., and D. Rosenfeld, (2008), Aerosol Cloud Precipitation Interactions. Part 1: The Nature and Sources of Cloud Active Aerosols, Earth-Science Reviews, 28: 13-41. 